\title{
Moral Argument and Liberal Toleration: Abortion and Homosexuality
}

\author{
Michael J. Sandel $\dagger$
}

People defend laws against abortion and hounosexual sodomy in two different ways: Some argue that abortion and hoinosexuality are morally reprehensible and therefore worthy of prohibition; others try to avoid passimg judgment on the morahty of these practices, and argue instead that, in a democracy, political majorities have the right to embody im law their moral convictions.

In a similar way, arguments against antiabortion and antisodomy laws take two different forms: Some say the laws are unjust because the practices they prohibit are morally permissible, indeed sometimes desirable; others oppose these laws without reference to the moral status of the practices at issue, and argue instead that individuals have a right to choose for themselves whether to engage in them.

These two styles of argument might be called, respectively, the "naive" and the "sophisticated." The naive view holds that the justice of laws depends on the moral worth of the conduct they prohibit or protect. The sophisticated view holds that the justice of such laws depends not on a substantive moral judgment about the conduct at stake, but instead on a more general theory about the respective claims of majority rule and individual rights, of democracy on the one hand, and liberty on the other.

I shall try in this paper to brimg out the truth in the naive view, which I take to be this: The justice (or mjustice) of laws against abortion and homosexual sodomy depends, at least in part, on the morality (or immorality) of those practices. ${ }^{1}$ This is the claim the sophisticated view rejects. In both its majoritarian and its hiberal versions, the sophisticated view tries to set aside or "bracket" controversial moral and rehioious conceptions for purposes of justice. It insists that the justification of laws be neutral among competing visions of the good life.

Copyright $\odot 1989$ by Michael J. Sandel. All rights reserved.

$\dagger$ Professor of Government, Harvard University.

1. I do not defend the stronger claim that the morality (or immorality) of a practice is the only relevant reason in deciding whether there should be a law against it. 
In practice, of course, these two kinds of argument can be difficult to distinguish. In the debate over cases like Roe v. Wade ${ }^{2}$ and Bowers $v$. Hardwick, ${ }^{3}$ both camps tend to advance the naive view under cover of the sophisticated. (Such is the prestige of the sophisticated way of arguing.) For example, those who would ban abortion and sodomy out of abhorrence often argue in the name of deference to democracy and judicial restraint. Similarly, those who want permissive laws because they approve of abortion and homosexuality often argue in the name of liberal toleration.

This is not to suggest that all instances of the sophisticated argument are disingenuous attempts to promote a substantive moral conviction. Those who argue that law should be neutral among competing conceptions of the good life offer various grounds for their claim, including most prominently the following:

(1) the relativist view says law should not affirm a particular moral conception because all morality is relative, and so there are no moral truths to affirm; (2) the utilitarian view argues that government neutrality will, for various reasons, promote the general welfare in the long run; (3) the voluntarist view holds that government should be neutral among conceptions of the good life in order to respect the capacity of persons as free citizens or autonomous agents to choose their conceptions for themselves; and (4) the minimalist, or pragmatic view says that, because people inevitably disagree about morality and religion, government should bracket these controversies for the sake of political agreement and social cooperation.

In order to bring out the truth in the naive way of arguing, I look to the actual arguments judges and commentators have made in recent cases dealing with abortion and homosexuality. Their arguments, unfailingly sophisticated, illustrate the difficulty of bracketing moral judgments for purposes of law. Because their reasons for trying to be neutral among conceptions of the good life are drawn primarily from voluntarist and minimalist assumptions, I focus on these arguments. Finally, although much of my argument criticizes leading theories of liberal toleration, I do not think it offers any comfort to majoritarianism. The cure for liberalism is not majoritarianism, but a keener appreciation of the role of substantive moral discourse in political and constitutional argument.

I

PRIVACY RIGHTS: INTIMACY AND AUTONOMY

In the constitutional right of privacy, the neutral state and the voluntarist conception of the person are often joined. In the case of abor-

2. 410 U.S. 113 (1973).

3. 478 U.S. 186 (1986). 
tion, for example, no state may, "by adopting one theory of life,"4 override a woman's right to decide "whether or not to terminate her pregnancy."5 Government may not enforce a particular moral view, however widely held, for "no individual should be compelled to surrender the freedom to make that decision for herself simply because her 'value preferences' are not shared by the majority."6

As with religious liberty and freedom of speech, so with privacy, the ideal of neutrality often reffects a voluntarist conception of human agency. Government must be neutral among conceptions of the good hife in order to respect the capacity of persons to choose their values and relationships for themselves. So close is the connection between privacy rights and the voluntarist conception of the self that commentators frequently assimilate the values of privacy and autonomy: Privacy rights are said to be "grounded in notions of individual autonomy," because "[t]he human dignity protected by constitutional guarantees would be seriously dimimished if people were not free to choose and adopt a lifestyle which allows expression of their uniqueness and individuality."7 In "recognizing a constitutional right to privacy," the Court has given effect to the view "that persons have the capacity to live autonomously and the right to exercise that capacity." against contraceptives "not only protect the individual who chooses not to procreate, but also the autonomy of a couple's association."9 They protect men and women "against an unchosen commitment" to unwanted children, and "against a compelled identification with the social role of parent."10

In Supreme Court decisions and dissents alike, the justices have often tied privacy rights to voluntarist assumptions. The Court has thus characterized laws banning the use of contraceptives as violating "the constitutional protection of individual autonomy in matters of childbearing." 11 It has defended the right to an abortion on the grounds that few decisions are "more properly private, or more basic to individual dignity

4. Roe v. Wade, 410 U.S. 113,162 (1973).

5. Id. at 153.

6. Thornburgh v. American College of Obstetricians \& Gynecologists, 476 U.S. 747, 777 (1986) (Stevens, J., concurring).

7. Eichbaum, Towards an Autonomy-Based Theory of Constitutional Privacy: Beyond the Ideology of Familial Privacy, 14 HARV. C.R.-C.L. L. REV. 361, 362, 365 (1979).

8. Richards, The Individual, the Family, and the Constitution: A Jurisprudential Perspective, 55 N.Y.U. L. REV. 1, 31 (1980).

9. Karst, The Freedom of Intimate Association, 89 YALE L.J. 624, 641 (1980). For articles discussing the connection between privacy and autonomy rights, see also Henkin, Privacy and Autonomy, 74 Colum. L. REV. 1410 (1974); Smith, The Constitution and Autonomy, 60 TEX. L. REV. 175 (1982); Wilkinson III \& White, Constitutional Protection for Personal Lifestyles, 62 CORNELl L. REV. 563 (1977).

10. Karst, supra note 9, at 641 .

11. Carey v. Population Services Int'l, 431 U.S. 678, 687 (1977). 
and autonomy, than a woman's decision ... whether to end her pregnancy." 12 Justice Douglas, concurring in an abortion case, emphasized that the right of privacy protects such liberties as "the autonomous control over the development and expression of one's intellect, interests, tastes, and personality," as well as "freedom of choice in the basic decisions of one's life respecting marriage, divorce, procreation, contraception, and the education and upbringing of children."13 Writing in dissent, Justice Marshall found a regulation limiting the hair length of policemen "inconsistent with the values of privacy, self-identity, autonomy, and personal integrity" he believed the Constitution was designed to protect. ${ }^{14}$ And four justices would have extended privacy protection to consensual homosexual activity on the grounds that "much of the richness of a relationship will come from the freedom an individual has to choose the form and nature of these intensely personal bonds." 15

Although the link between privacy and autonomy is now so familiar as to seem natural, even necessary, the right of privacy need not presuppose a voluntarist conception of the person. In fact, through most of its history in American law, the right of privacy has implied neither the ideal of the neutral state nor the ideal of a self freely choosing its aims and attachments.

Where the contemporary right of privacy is the right to engage in certain conduct without government restraint, the traditional version is the right to keep certain personal facts from public view. The new privacy protects a person's "independence in making certain kinds of important decisions," whereas the old privacy protects a person's interest "in avoiding disclosure of personal matters." 16

The tendency to identify privacy with autonomy not only obscures these shifting understandings of privacy; it also restricts the range of reasons for protecting it. Although the new privacy typically relies on voluntarist justifications, it can also be justified in other ways. A right to be free of governmental interference in matters of marriage, for example, can be defended not only in the name of individual choice, but also in the name of the intrinsic value or social importance of the practice it protects. As the Court has acknowledged, "certain kinds of personal bonds have played a critical role in the culture and traditions of the Nation by cultivating and transmitting shared ideals and beliefs; they thereby foster diversity and act as critical buffers between the individual and the power (1986)

12. Thornburgh v. American College of Obstetricians \& Gynecologists, 476 U.S. 747, 772

13. Doe v. Bolton, 410 U.S. 179, 211 (1973) (Douglas, J., concurring) (emphasis omitted).

14. Kelley v. Johnson, 425 U.S. 238, 251 (1976) (Marshall, J., dissenting).

15. Bowers v. Hardwick, 478 U.S. 186, 205 (1986) (Blackmun, J., dissenting).

16. Whalen v. Roe, 429 U.S. 589, 599-600 (1977). 
of the State."17 The Court's greater tendency, however, has been to view privacy in voluntarist terms, as protecting "the ability independently to define one's identity." 18

\section{II}

\section{From the Old Privacy to the New}

The right to privacy first gained legal recognition in the United States as a doctrine of tort law, not constitutional law. In an influential article in 1890, Louis Brandeis, then a Boston lawyer, and his one-time law partner Samuel Warren argued that the civil law should protect "the right to privacy." 19 Far from later-day concerns with sexual freedoms, Brandeis and Warren's privacy was quaint by comparison, concerned with the publication of high society gossip by the sensationalist press, or the unauthorized use of people's portraits in advertising. ${ }^{20}$ Gradually at first, then more frequently in the 1930s, this right to privacy gained recognition in the civil law of most states. ${ }^{21}$ Prior to the 1960 s, however, privacy received scant attention in constitutional law.

Two members of the Supreine Court first addressed the right of privacy as such in 1961 when a Connecticut pharmacist challenged the state's ban on contraceptives in Poe v. Ullman. ${ }^{22}$ Although the majority dismissed the case on techmical grounds, ${ }^{23}$ Justices Douglas and Harlan dissented, arguing that the law violated the right of privacy. The privacy they defended was privacy in the traditional sense. The right at stake was not the right to use contraceptives but the right to be free of the surveillance that enforcement would require. "If we imagine a regime of full enforceinent of the law," wrote Douglas, "we would reach the point where search warrants issued and officers appeared in bedrooms to find out what went on.... If [the State] can make this law, it can enforce it. And proof of its violation necessarily involves an inquiry into the relations between man and wife." 24 Banning the sale of contraceptives would be different from banning their use, Douglas observed. Banning the sale would restrict access to contraceptives but would not expose intimate relations to public inspection. Enforcement would take police to

17. Roberts v. United States Jaycees, 468 U.S. 609, 618-19 (1984).

18. Id. at 619 .

19. Warren \& Brandeis, The Right to Privacy, 4 HARV. L. Rev. 193 (1890).

20. Id. at 195-96.

21. Prosser, Privacy, 48 Calif. L. Rev. 383 (1960) (discussing the ensuing recognition and development of a right to privacy).

22. 367 U.S. 497 (1961).

23. Id. at 509.

24. Id. at 519-21 (Douglas, J., dissenting). 
the drugstore, not the bedroom, and so would not offend privacy in the traditional sense. ${ }^{25}$

Justice Harlan also objected to the law on grounds that distinguish the old privacy from the new. He did not object that the law against contraceptives failed to be neutral among competing moral conceptions. Although Harlan acknowledged that the law was based on the belief that contraception is immoral in itself, and encourages such "dissolute action" as fornication and adultery by minimizing their "disastrous consequence," 26 he did not find this failure of neutrality contrary to the Constitution. In a statement clearly opposed to the strictures of neutrality, Harlan argued that morality is a legitimate concern of government.

The very inclusion of the category of morality among state concerns indicates that society is not limited in its objects only to the physical wellbeing of the community, but has traditionally concerned itself with the moral soundness of its people as well. Indeed to attempt a line between public behavior and that which is purely consensual or solitary would be to withdraw from community concern a range of subjects with which every society in civilized times has found it necessary to deal. ${ }^{27}$

Though he rejected the ideal of the neutral state, Harlan did not conclude that Connecticut could prohibit married couples from using contraceptives. Like Douglas, he reasoned that enforcing the law would intrude on the privacy essential to the prized institution of marriage. He objected to the violation of privacy in the traditional sense, to "the intrusion of the whole machinery of the criminal law into the very heart of marital privacy, requiring husband and wife to render account before a criminal tribunal of their uses of that intimacy."28 According to Harlan, the state was entitled to embody in law the belief that contraception is immoral, but not to implement "the obnoxiously intrnsive means it ha[d] chosen to effectuate that policy."29

Four years later, in Griswold v. Connecticut, ${ }^{30}$ the dissenters prevailed. The Supreme Court invalidated Connecticut's law against contraceptives and for the first time explicitly recognized a constitutional right of privacy. Although the right was located in the Constitution rather than tort law, it remained tied to the traditional notion of privacy as the interest in keeping intimate affairs from public view. The violation of privacy consisted in the intrusion required to enforce the law, not the restriction on the freedom to use contraceptives. "Would we allow the police to search the sacred precincts of marital bedrooms for telltale signs

\footnotetext{
25. Id. at 519 .

26. Id. at 545 (Harlan, J., dissenting).

27. Id. at $545-46$.

28. Id. at 553 .

29. Id. at 554 .

30. 381 U.S. 479 (1965).
} 
of the use of contraceptives?," wrote Justice Douglas for the Court. "The very idea is repulsive to the notions of privacy surrounding the marriage relationship." 31

The justification for the right was not voluntarist but unabashedly teleological; the privacy the Court vindicated was not for the sake of lettiug people lead their sexual hives as they choose, but rather for the sake of affirming and protecting the social institution of marriage.

Marriage is a coming together for better or for worse, hopefully enduring, and intimate to the degree of being sacred. It is an association that promotes a way of life, ... a harmony in tiving, ... a bilateral loyalty .... [I]t is an association for as noble a purpose as any involved in our prior decisions. $^{32}$

Although coinmentators and judges often view Griswold as a dramatic constitutional departure, the privacy right it proclaimed was consistent with traditional notions of privacy going back to the turn of the century. Froin the standpoint of shifting privacy conceptions, the inore decisive turn came seven years later in Eisenstadt v. Baird, ${ }^{33}$ a seemingly similar case. Like Griswold, it involved a state law restricting contraceptives. In Eisenstadt, however, the challenged law restricted the distribution of contraceptives, not their use. While it therefore limited access to contraceptives, its enforcement could not be said to require governmental surveillance of intinate activities. It did not violate privacy in the traditional sense. ${ }^{34}$ Furthermore, the law prohibited distributing contraceptives only to uninarried persons, and so did not burden the institution of marriage as the Connecticut law did.

Despite these differences, the Supreme Court struck down the law with only a single dissent. Its decision involved two innovations, one explicit, the other unacknowledged. The explicit innovation redescribed the bearers of privacy rights from persons qua participants in the social institution of marriage to persons qua individuals, independent of their roles or attachments. As the Court explained, "It is true that in Griswold the right of privacy in question inhered in the inarital relationship. Yet the marital couple is not an independent entity with a inind and heart of its own, but an association of two individuals each with a separate intellectual and enotional makeup."35

The subtler, though no less fateful change in Eisenstadt was in the shift from the old privacy to the new. Rather than conceiving privacy as freedoin from surveillance or disclosure of intimate affairs, the Court

31. Id. at $485-86$.

32. Id. at 486 .

33. 405 U.S. 438 (1972).

34. In fact, the case arose when a man was convicted for giving away a contraceptive device at a public lecture. Id. at 440 .

35. Id. at 453 . 
found that the right to privacy now protected the freedom to engage in certain activities without governmental restriction. Although privacy in Griswold prevented intrusion into "the sacred precincts of marital bedrooms," ${ }^{36}$ privacy in Eisenstadt prevented intrusion into decisions of certain kinds. Moreover, as the meaning of privacy changed, so did its justification. The Court protected privacy in Eisenstadt not for the social practices it promoted but for the individual choice it secured. "If the right of privacy means anything, it is the right of the individual, married or single, to be free from unwarranted governmental intrusion into matters so fundamentally affecting a person as the decision whether to bear or beget a child." 37

One year later, in Roe v. Wade, ${ }^{38}$ the Supreme Court gave the new privacy its most controversial application by striking down a Texas law against abortion and extending privacy to "encompass a woman's decision whether or not to terminate her pregnancy." 39 First with contraception, then with abortion, the right of privacy had become the right to make certain sorts of choices, free of interference by the state. The choice had also to be free of interference by husbands or parents. In Planned Parenthood of Missouri v. Danforth, ${ }^{40}$ the Court struck down a law requiring a husband's consent, or parental consent in the case of unmarried minors, as a condition for an abortion. Since the state may not prevent even minors from having abortions in the first trimester, it cannot delegate to "a third party" such as a husband or parent the authority to do so. ${ }^{41}$

The voluntarist grounds of the new privacy found explicit statement in a 1977 case invalidating a New York law prohibiting the sale of contraceptives to minors under age sixteen.$^{42}$ For the first time, the Court used the language of autonomy to describe the interest privacy protects, and argued openly for the shift from the old privacy to the new. Writing for the Court in Carey v. Population Services International, Justice Brennan admitted that Griswold focused on the fact that a law forbidding the use of contraceptives can bring the police into marital bedrooms. ${ }^{43}$ "But subsequent decisions have made clear that the constitutional protection

36. Griswold, 381 U.S. at 485.

37. Eisenstadt, 405 U.S. at 453. The Court's opinion in Eisenstadt camouflages the shift from the old privacy to the new with a false hypothetical premise: "If under Griswold the distribution of contraceptives to married persons cannot be prohibited, a ban on distribution to unmarried persons would be equally impermissible." Id. But Griswold did not hold that distribution to married persons cannot be prohibited.

38. 410 U.S. 113 (1973).

39. Id. at 153 .

40. 428 U.S. 52 (1976).

41. Id. at 69,75 .

42. Carey v. Population Services Int'l, 431 U.S. 678 (1977).

43. Id. at 687. 
of individual autonomy in matters of childbearing is not dependent on that element." ${ }^{\text {"44 }}$ Surveying the previous cases, he emphasized that Eisenstadt protected the "decision whether to bear or beget a child,"45 and Roe protected "a woman's decision whether or not to terminate her pregnancy." 46 He concluded that "the teaching of Griswold is that the Constitution protects individual decisions in matters of childbearing from unjustified intrusion by the State." ${ }^{\text {47 }}$

Given the voluntarist imterpretation of privacy, restricting the sale of contraceptives violates privacy as harshly as banning their use; the one limits choice as surely as the other. "Indeed, in practice," Brennan observed, "a prohibition against all sales, since more easily and less offensively enforced, might have an even more devastating effect upon the freedom to choose contraception." ${ }^{" 48}$ Ironically, the very fact that a ban on sales does not threaten the old privacy makes it a greater threat to the new.

Later decisions upholding abortion rights also used the language of autonoiny to describe the privacy interest at stake. The Court held in a recent opinion that "[f]ew decisions are . . . inore properly private, or more basic to individual diguity and autonony than a woman's decision ... whether to end her preguancy. A woman's right to inake that choice freely is fundainental." 49

Despite its increasing tendency to identify privacy with autonomy, the Court refused, in a 5-4 decision, to extend privacy protection to consensual homosexual activity. Writing for the inajority, Justice White emphasized that the Court's previous privacy cases protected choice only with respect to child rearing and education, family relationships, procreation, marriage, contraception, and abortion. "[W]e think it evident," he held, "that none of the rights announced in those cases bears any resemblance to the claimed constitutional right of homosexuals to engage in acts of sodomy ....."so $\mathrm{He}$ also rejected the claim that Georgia's citizens could not embody in law their belief "that hoinosexual sodomy is immoral and unacceptable." 1 Neutrality to the contrary, "[t]he law ... is constantly based on notions of morality, and if all laws representing

44. Id.

45. Id. (quoting Eisenstadt, 405 U.S. at 453) (emphasis added in Carey).

46. Id. (quoting Roe, 410 U.S. at 153) (emphasis added in Carey).

47. Id.

48. Id. at 688 .

49. Thornburgh v. American College of Obstetricians \& Gynecologists, 776 U.S. 747, 772 (1986).

50. Bowers v. Hardwick, 478 U.S. 186, 190-91 (1986).

51. Id. at 196. 
essentially moral choices are to be invalidated under the Due Process Clause, the courts will be very busy indeed."52

Writing for the four dissenters, Justice Blackmun argued that the Court's previous privacy decisions did not depend on the virtue of the practices they protected but on the principle of free individual choice in intimate matters. "We protect those rights not because they contribute ... to the general public welfare, but because they form so central a part of an individual's life. '[T]he concept of privacy embodies the "moral fact that a person belongs to himself and not others nor to society as a whole." ,"53

Blackmun argued for the application of earlier privacy rulings in the considerations of homosexual practices by casting the Court's concern for conventional family ties in individualist terms: "We protect the decision whether to have a child because parenthood alters so dramatically an individual's self-definition .... And we protect the family because it contributes so powerfully to the happiness of individuals, not because of a preference for stereotypical households." 54 Because the right of privacy in sexual relationships protects "the freedom an individual has to choose the form and nature of these intensely personal bonds,"ss it protects homosexual activity no less than other intimate choices.

Defending the ideal of the neutral state, Blackmun added that traditional religious condemnations of homosexuality "give[] the State no license to impose their judgments on the entire citizenry."56 To the contrary, the State's appeal to religious teachings against homosexuality undermines its claim that the law "represents a legitimate use of secular coercive power."s7

Despite the Court's reluctance to extend privacy rights to homosexuals, the privacy cases of the last twenty-five years offer ample evidence of assumptions drawn from the liberal conception of the person. They also raise two questions about the liberalism they reflect: First whether bracketing controversial moral issues is even possible; and second

52. Id.

53. Id. at 204 (Blackmun, J., dissenting) (quoting Thornburgh v. American College of Obstetricians \& Gynecologists, 476 U.S. at 777 n.5 (Stcvens, J., concurring) (quoting Fried, Correspondence, 6 PHIL. \& PuB. Aff. 288-89 (1977))).

54. Id. at 205.

55. Id.

56. Id. at 211.

57. Id. In striking down a similar sodomy law, the New York Court of Appeals clearly expressed the idea that government must be neutral among competing conceptions of the good. "[IIt is not the function of the Penal Law in our governmental policy to provide either a medium for the articulation or the apparatus for the intended enforcement of moral or theological values." People v. Onofre, 51 N.Y.2d 476, 488 n.3, 415 N.E.2d 936, 940 n.3, 434 N.Y.S.2d 947, 951 n.3 (1980), cert. denied, 451 U.S. 987 (1981). 
whether the voluntarist conception of privacy limits the range of reasons for protecting privacy.

\section{III}

\section{The Minimalist Case for Toleration: Abortion}

Unlike the voluntarist grounds for the neutral state, mininuahst hiberalism seeks a conception of justice that is political not philosophical, that does not presuppose any particular conception of the person, autononious or otherwise. It proposes bracketing controversial nioral and religious issues for the sake of securing social cooperation in the face of disagreenient about ends, not for the sake of such "coniprehensive" liberal ideals as autonony or individuality. ${ }^{58}$ One objection to mininialist liberalism is that the case for bracketing a particular nioral or religious controversy may partly depend on an implicit answer to the controversy it purports to bracket. In the case of abortion, for example, the niore confident we are that fetuses are, in the relevant nioral sense, different fron babies, the nore confident we can be in bracketing the question about the nioral status of fetuses for political purposes.

The Court's argument in Roe v. Wade ${ }^{59}$ illustrates the difficulty of deciding constitutional cases by bracketing controversial noral and religious issues. Although the Court claimed to be neutral on the question of when life begins, its decision presupposes a particular answer to that question. The Court began by observing that Texas' law against abortion rests upon a particular theory of when life begins. "Texas urges that ... life begins at conception and is present througlout pregnancy, and that, therefore, the State has a compelling interest in protecting that life frons and after conception." 60

The Court then claimed to be neutral on tliat question: "We need not resolve tlie difficult question of when life begins. When those tramed in the respective disciplines of medicine, plilosophy, and theology are unable to arrive at any consensus, the judiciary . . . is not in a position to speculate as to the answer." 61 It then noted "the wide divergence of thinking on this most sensitive and difficult question," throughout the western tradition and in the law of various American states. ${ }^{62}$

From this survey, the Court concluded that "tlie unborn liave never been recognized in the law as persons in the whole sense." ${ }^{33}$ Accord-

58. Rawls, Justice as Fairness: Political Not Metaphysical, 14 Ph1L. \& PuB. Afr. 223, 245 (1985); Rorty, The Priority of Democracy to Philosophy, in The V1RGinia Statute for Religious FREEDOM 257 (M. Peterson \& R. Vaughan eds. 1988).

59. 410 U.S. 113 (1973).

60. Id. at 159 .

61. Id.

62. Id. at 160-62.

63. Id. at 162 . 
ingly, it argued that Texas was wrong to embody in law a particular theory of life. Since no theory was conclusive, it held that Texas erred in "adopting one theory of life ... [which would] override the rights of the pregnant woman that are at stake." 64

However, contrary to its professions of neutrality, the Court's decision presupposed a particular answer to the question it claimed to bracket.

With respect to the State's important and legitimate interest in potential life, the "compelling" point is at viability. This is so because the fetus then presumably has the capability of meaningful life outside the mother's womb. State regulation protective of fetal life after viability thus has both logical and biological justifications. ${ }^{65}$

That the Court's decision in Roe presupposes a particular answer to the question it purports to bracket is no argument against its decision, only an argument against its claim to have bracketed the controversial question of when life begins. It does not replace Texas' theory of life with a neutral stance, but with a different theory of its own.

The minimalist case for neutrality is subject to a further difficulty: Even given an agreement to bracket controversial moral and religious issues for the sake of social cooperation, it may be controversial what counts as bracketing; and this controversy may require for its solution either a substantive evaluation of the interests at stake, or the autonomous conception of agency that minimalist liberalism resolves to avoid. Thornburgh v. American College of Obstetricians \& Gynecologists, ${ }^{66}$ a 1986 abortion case upholding Roe, offers an example of this difficulty.

Writing in dissent, Justice White urged the Court in Thornburgh to overrule Roe v. Wade and "return the issue to the people." $67 \mathrm{He}$ agreed that abortion was a controversial moral issue, but argued that the best way for the Court to bracket this controversy was to let each state decide the question for itself. He proposed, in effect, to bracket the intractable controversy over abortion as Stephen Douglas proposed to bracket the intractable controversy over slavery-by refusing to impose a single answer on the country as a whole. "Abortion is a hotly contested moral and political issue," White wrote. "Such issues, in our society, are to be resolved by the will of the people, either as expressed through legislation or through the general principles they have already incorporated into the Constitution they have adopted." ${ }^{68}$ For the Court to do otherwise is not
64. Id.
65. Id. at 163 .
66. 476 U.S. 747 (1986).
67. Id. at 797 (White, J., dissenting).
68. Id. at 796 . 
to be neutral but to "impose its own controversial choices of value upon the people." 69

Justice Stevens responded to White by arguing for a different way of bracketing. Given the controversial moral issues at stake, he urged that individual women, not legislatures, should decide the question for themselves. For the Court to insist that women be free to choose for themselves is not to impose the Court's values, but simply to prevent local majorities from imposing their values on individuals. "[N]o individual should be compelled to surrender the freedom to make that decision for herself simply because her 'value preferences' are not shared by the majority." "For Stevens, the basic question is not which theory of hife is true, but "whether the 'abortion decision' should be made by the individual or by the majority in the unrestrained imposition of its own, extraconstitutional value preferences." "71

What is striking is that both ways of bracketing are in principle consistent with mimimalist liberalism: The practical interest in social cooperation under conditions of disagreement about the good offers no grounds for choosing one over the other. Even given agreement to bracket an intractable moral or rehigious controversy for the sake of social cooperation, it may still be unclear what counts as bracketing. Moreover, resolving that question-deciding between White's position and Stevens'requires either a substantive view about the moral and religious interests at stake or an autonomous conception of the person such as the voluntarist view affirms. Both solutions, however, would deny minimalist liberalism its mimimalism; each would implicate its putatively political conception of justice in precisely the moral and philosophical commitments that it seeks to avoid.

\section{IV}

\section{THE VOLUNTARIST CASE FOR TOLERATION: HOMOSEXUALITY}

The dissenters' argument for toleration in Bowers v. Hardwick ${ }^{72}$ illustrates the difficulities with the version of liberalism that ties toleration to autonomy rights alone. In refusing to extend the right of privacy to homosexuals, the majority in Bowers declared that none of the rights announced in earlier privacy cases resembled the rights homosexuals

69. Id. at 790. Justice Harlan suggested a similar way of bracketing the moral controversy over contraception in Poe v. Ullman, 367 U.S. 497, 547 (1961) (Harlan, J., dissenting): "[T] controversial nature of these questions would, I think, require us to hesitate long before concluding that the Constitution precluded Connecticut from choosing as it has among these various views."

70. Id. at 777 (Stevens, J., concurring).

71. Id. at 777-78 (quoting Id. at 794 (White, J. dissenting)).

72. 478 U.S. 186 (1986). 
were seeking: "No connection between family, marriage, or procreation on the one hand and homosexual activity on the other has been demonstrated ...."73 Any reply to the Court's position would have to show some connection between the practices already subject to privacy protection and the homosexual practices not yet protected. What then is the resemblance between heterosexual intimacies on the one hand, and homosexual intimacies on the other, such that both are entitled to a constitutional right of privacy?

This question might be answered in at least two different ways-one voluntarist, the other substantive. The first argues from the autonomy the practices reflect, whereas the second appeals to the human goods the practices realize. The voluntarist answer holds that people should be free to choose their intimate associations for themselves, regardless of the virtue or popularity of the practices they choose so long as they do not harm others. In this view, homosexual relationships resemble the heterosexual relationships the Court has already protected in that all reflect the choices of autonomous selves.

By contrast, the substantive answer claims that much that is valuable in conventional marriage is also present in homosexual unions. In this view, the connection between heterosexual and homosexual relations is not that both result from individual choice but that both realize important human goods. Rather than rely on autonomy alone, this second line of reply articulates the virtues homosexual intimacy may share with heterosexual intimacy, along with any distinctive virtues of its own. It defends homosexual privacy the way Griswold defended marital privacy, by arguing that, like marriage, homosexual union may also be "intimate to the degree of being sacred . . . a harmony in living . . . a bilateral loyalty," an association for a "noble .. . purpose."74

Of these two possible replies, the dissenters in Bowers relied wholly on the first. Rather than protect homosexual intimacies for the human goods they share with intimacies the Court already protects, Justice Blackmun cast the Court's earlier cases in individualist terms, and found their reading applied equally to homosexuality because "much of the richness of a relationship will come from the freedom an individual has to choose the form and nature of these intensely personal bonds."75 At issue was not homosexuality as such but respect for the fact that "different individuals will make different choices" in deciding how to conduct their lives. ${ }^{76}$

\footnotetext{
73. Id. at 191.

74. The phrases are from Griswold v. Connecticut, 381 U.S. 479, 486 (1965).

75. 478 U.S. at 205 (Blackmun, J., dissenting) (emphasis added).

76. Id. at 206.
} 
Justice Stevens, in a separate dissent, also avoided referring to the values homosexual intimacy may share with heterosexual love. Instead, he wrote broadly of " "the individual's right to make certain unusually important decisions" " and "respect for the dignity of individual choice," "77 rejecting the notion that such liberty belongs to heterosexuals alone. "Froin the standpoint of the individual, the homosexual and the heterosexual have the same interest in deciding how he will live his own life, and, more narrowly, how he will conduct himself in his personal and voluntary associations with his companions."78

The voluntarist argument so dominates the Bowers dissents that it seems difficult to imagine a judicial rendering of the substantive view. But a glimmer of this view can be found in the appeals court opinion in the saine case. ${ }^{79}$ The United States Court of Appeals had ruled in Hardwick's favor and had struck down the law under which he was convicted. Like Blackmun and Stevens, the appeals court constructed an analogy between privacy in marriage and privacy in homosexual relations. But unlike the Supreme Court dissenters, it did not rest the analogy on voluntarist grounds alone. It argued instead that both practices may realize important human goods.

The inarital relationship is significant, wrote the court of appeals, not only because of its procreative purpose but also "because of the unsurpassed opportumity for mutual support and self-expression that it provides." that "[m]arriage is a coming together for better or for worse, hopefully enduring, and intimate to the degree of being sacred."81 And it went on to suggest that the quahties the Court so prized in Griswold could be present in hoinosexual unions as well: "For some, the sexual activity in question here serves the same purpose as the intimacy of marriage." 82

Ironically, this way of extending privacy rights to homosexuals depends on an "old-fashioned" reading of Griswold as protecting the human goods realized in marriage, a reading the Court has long since renounced in favor of an individualist reading. ${ }^{83}$ By drawing on the teleological dimension of Griswold, the substantive case for homosexual privacy offends the liberalism that insists on neutrality. It grounds the right

77. Id. at 217 (Stevens, J., dissenting) (quoting Fitzgerald v. Porter Memorial Hospital, 523 F.2d 716, 719-20 (7th Cir. 1975), cert. denied, 425 U.S. 916 (1976)).

78. Id. at 218-19.

79. Hardwick v. Bowers, 760 F.2d 1202 (11th Cir. 1985), rev'd, 476 U.S. 747 (1986).

80. Id. at 1211-12.

81. Id. at 1212 (quoting Griswold v. Connecticut, 381 U.S. 479, 486 (1965)).

82. Id. at 1212 .

83. For individualist readings of Griswold, see Eisenstadt v. Baird, 405 U.S. 438, 453 (1972) and Carey v. Population Services Int'1, 431 U.S. 678, 687 (1977). 
of privacy on the good of the practice it would protect, and so fails to be neutral among conceptions of the good.

The more frequently employed precedent for homosexual rights is not Griswold but Stanley v. Georgia, ${ }^{84}$ which upheld the right to possess obscene materials in the privacy of one's home. Stanley did not hold that the obscene films found in the defendant's bedroom served a "noble purpose," only that he had a right to view them in private. The toleration Stanley defended was wholly independent of the value or importance of the thing being tolerated. ${ }^{85}$

In the 1980 case of People v. Onofre, ${ }^{86}$ the New York Court of Appeals vindicated privacy rights for homosexuals on precisely these grounds. The court reasoned that if, following Stanley, there is a right to the "satisfaction of sexual desires by resort to material condemned as obscene," there should also be a right "to seek sexual gratification from what at least once was commonly regarded as 'deviant' conduct," so long as it is private and consensual. ${ }^{87}$ The court emphasized its neutrality toward the conduct it protected: "We express no view as to any theological, moral or psychological evaluation of consensual sodomy. These are aspects of the issue on which informed, competent authorities and individuals may and do differ." 88 The court's role was simply to ensure that the State bracketed these competing moral views, rather than embodying any one of them in law. ${ }^{89}$

The case for toleration that brackets the morality of homosexuality has a powerful appeal. In the face of deep disagreement about values, it seems to ask the least of the contending parties. It offers social peace and respect for rights without the need for moral conversion. Those who view sodomy as sin need not be persuaded to change their minds, only to tolerate those who practice it in private. By insisting only that each respect the freedom of others to live the lives they choose, this toleration promises a basis for political agreement that does not await shared conceptions of morality.

Despite its promise, however, the neutral case for toleration is subject to two related difficulties. First, as a practical matter, it is by no means clear that social cooperation can be secured on the strength of

84. 394 U.S. 557 (1969).

85. Id. at 564-66, 568 ("This right to receive information and ideas, regardless of their social worth, is fundamental to our free society.... [T] he States retain broad power to regulate obscenity; that power simply does not extend to mere possession by the individual in the privacy of his own home.") (emphasis added) (citation omitted).

86. 51 N.Y.2d 476, 415 N.E.2d 936, 434 N.Y.S.2d 947 (1980), cert. denied, 451 U.S. 987 (1981).

87. Id. at $487-88,415$ N.E. $2 \mathrm{~d}$ at $939-41,434$ N.Y.S.2d at $950-51$.

88. Id. at 488 n.3, 415 N.E.2d at 940 n.3, 434 N.Y.S.2d at 951 n.3.

89. Id. 
autonomy rights alone, absent some measure of agreement on the moral permissibility of the practices at issue. It may not be accidental that the first practices subject to the right of privacy were accorded constitutional protection in cases that spoke of the sanctity of marriage and procreation. Only later did the Court abstract privacy rights from these practices and protect them without reference to the human goods they were once thought to make possible. This suggests that the voluntarist justification of privacy rights is dependent-politically as well as philosophically-on some measure of agreement that the practices protected are morally permissible.

A second difficulty with the voluntarist case for toleration concerns the quality of respect it secures. As the New York case suggests, the analogy with Stanley tolerates homosexuality at the price of demeaning it; it puts homosexual intimacy on a par with obscenity-a base thing that should nonetheless be tolerated so long as it takes place in private. If Stanley rather than Griswold is the relevant analogy, the interest at stake is bound to be reduced, as the New York court reduced it, to "sexual gratification." (The only intimate relationship at stake in Stanley was between a man and his pornography.)

The majority in Bowers exploited this assumption by ridiculing the notion of a "fundamental right to engage in homosexual sodomy." 90 The obvious reply is that Bowers is no more about a right to homosexual sodomy than Griswold was about a right to heterosexual intercourse. But by refusing to articulate the human goods that homosexual intimacy may share with heterosexual unions, the voluntarist case for toleration forfeits the analogy with Griswold and makes the ridicule difficult to refute.

The problem with the neutral case for toleration is the opposite side of its appeal; it leaves wholly unchallenged the adverse views of homosexuality itself. Unless those views can be plausibly addressed, even a Court ruling in their favor is unlikely to win for homosexuals more than a thin and fragile toleration. A fuller respect would require, if not admiration, at least some appreciation of the hives homosexuals live. Such appreciation, however, is unlikely to be cultivated by a legal and political discourse conducted in terms of autonomy rights alone.

The liberal may reply that autonomy arguments in court need not foreclose more substantive, affirmative arguments elsewhere; bracketing moral argument for constitutional purposes does not mean bracketing moral argument altogether. Once their freedom of choice in sexual practice is secured, homosexuals can seek, by argument and example, to win from their fellow citizens a deeper respect than autonomy can supply.

90. Bowers v. Hardwick, 478 U.S. 186, 191 (1986). 
The liberal reply, however, underestimates the extent to which constitutional discourse has come to constitute the terms of political discourse in American public life. While most at home in constitutional law, the main motifs of contemporary liberalism-rights as trumps, the neutral state, and the unencumbered self-figure with increasing prominence in our moral and political culture. Assumptions drawn from constitutional discourse increasingly set the terms of political debate in general.

\section{CONCLUSION}

Admittedly, the tendency to bracket substantive moral questions makes it difficult to argue for toleration in the language of the good. Defining privacy rights by defending the practices privacy protects seems either reckless or quaint; reckless because it rests so much on moral argument, quaint because it recalls the traditional view that ties the case for privacy to the merits of the conduct privacy protects. But as the abortion and sodomy cases illustrate, the attempt to bracket moral questions faces difficulties of its own. They suggest the truth in the "naive" view, that the justice or injustice of laws against abortion and homosexual sodomy may have something to do with the morality or immorality of these practices after all. 